\title{
Seasonal availability of edible underground and aboveground carbohydrate resources to human foragers on the Cape south coast, South Africa
}

Jan C De Vynck, Richard M Cowling, Alastair J Potts, Curtis W Marean

The coastal environments of South Africa's Cape Floristic Region (CFR) provide some of the earliest and most abundant evidence for the emergence of cognitively modern humans. In particular, the south coast of the CFR provided a uniquely diverse resource base for hunter-gatherers, which included marine shellfish, game, and carbohydrate-bearing plants, especially those with underground storage organs (USOS). It has been hypothesized that these resources underpinned the continuity of human occupation in the region since the Middle Pleistocene. Very little research has been conducted on the foraging potential of carbohydrate resources in the CFR. This study focuses on the seasonal availability of plants with edible carbohydrate at six-weekly intervals over a two-year period in four vegetation types on South Africa's Cape south coast. Different plant species were considered available to foragers if the edible carbohydrate was directly (i.e. above-ground edible portions) or indirectly (above-ground indications to below-ground edible portions) visible to an expert botanist familiar with this landscape. A total of 52 edible plant species were recorded across all vegetation types. Of these, 33 species were geophytes with edible USOs and 21 species had aboveground edible carbohydrates. Limestone Fynbos had the richest flora, followed by Strandveld, Renosterveld and lastly, Sand Fynbos. The availability of plant species differed across vegetation types and between survey years. The number of available USO species was highest for a six-month period from winter to early summer (Jul-Dec) across all vegetation types. Months of lowest species' availability were in mid-summer to early autumn (Jan-Apr); the early winter (May-Jun) values were variable, being highest in Limestone Fynbos. However, even during the late summer carbohydrate "crunch", 25 carbohydrate bearing species were visible across the four vegetation types. To establish a robust resource landscape will require additional spatial mapping of plant species abundances. Nonetheless, our results demonstrate that plantbased carbohydrate resources available to Stone Age foragers of the Cape south coast, especially USOs belonging to the Iridaceae family, are likely to have comprised a reliable and nutritious source of calories over most of the year. 


\section{Seasonal availability of edible underground and aboveground carbohydrate} 2 resources to human foragers on the Cape south coast, South Africa

3

4 Jan C. De Vynck ${ }^{1}$, Richard M. Cowling ${ }^{1}$, Alastair J. Potts ${ }^{1}$ and Curtis W. Marean ${ }^{1,2}$ 5

$6 \quad{ }^{1}$ Centre for Coastal Palaeosciences, Nelson Mandela Metropolitan University, PO Box 77 000, 7 Port Elizabeth, 6031, Eastern Cape, South Africa

8

9 2Institute of Human Origins, School of Human Evolution and Social Change, PO Box 872402, 10 Arizona State University, Tempe, Arizona 85287-2402, USA

11

12

13

14

15

16

17

18

19

20

21

22

23

24

25

26

27

28

29

30 


\section{$31 \quad$ Abstract}

32

33 The coastal environments of South Africa's Cape Floristic Region (CFR) provide some of the

34

35

36

37

38

39

40

41

42

43

44 45

46

47

48

49

50

51

52

53

54

55

56

57 58

59

60 earliest and most abundant evidence for the emergence of cognitively modern humans. In particular, the south coast of the CFR provided a uniquely diverse resource base for huntergatherers, which included marine shellfish, game, and carbohydrate-bearing plants, especially those with underground storage organs (USOs). It has been hypothesized that these resources underpinned the continuity of human occupation in the region since the Middle Pleistocene. Very little research has been conducted on the foraging potential of carbohydrate resources in the CFR. This study focuses on the seasonal availability of plants with edible carbohydrate at sixweekly intervals over a two-year period in four vegetation types on South Africa's Cape south coast. Different plant species were considered available to foragers if the edible carbohydrate was directly (i.e. above-ground edible portions) or indirectly (above-ground indications to below-ground edible portions) visible to an expert botanist familiar with this landscape. A total of 52 edible plant species were recorded across all vegetation types. Of these, 33 species were geophytes with edible USOs and 21 species had aboveground edible carbohydrates. Limestone Fynbos had the richest flora, followed by Strandveld, Renosterveld and lastly, Sand Fynbos. The availability of plant species differed across vegetation types and between survey years. The number of available USO species was highest for a six-month period from winter to early summer (Jul-Dec) across all vegetation types. Months of lowest species' availability were in mid-summer to early autumn (Jan-Apr); the early winter (May-Jun) values were variable, being highest in Limestone Fynbos. However, even during the late summer carbohydrate "crunch", 25 carbohydrate bearing species were visible across the four vegetation types. To establish a robust resource landscape will require additional spatial mapping of plant species abundances. Nonetheless, our results demonstrate that plant-based carbohydrate resources available to Stone Age foragers of the Cape south coast, especially USOs belonging to the Iridaceae family, are likely to have comprised a reliable and nutritious source of calories over most of the year. 


\section{Introduction}

63

64 The Cape south coast has likely been occupied by hominins for at least the last 1 million years 65 and the earliest archaeological remains attributable to Homo sapiens dates to approximately 66 160,000 years ago (Jerardino \& Marean, 2010). The archaeological record on the Cape south coast for the period between 160,000 and 50,000 years is unusually data rich and well dated. This region and time period is crucial to our understanding of modern human origins as it provides some of the earliest evidence for the emergence of complex behaviours associated with cognitively modern humans, making it highly significant to human origins studies (Marean et al.,

71 2014). The archaeological record documents human occupation during periods of glacial

72 maxima, such as Marine Isotope Stages 6 and 4, when climatic conditions over much of the rest

73 of Africa were too harsh for human occupation or could sustain only very small populations

74 (Bar-Matthews et al., 2010; Marean et al., 2014). It has been hypothesised that the richness of

75 the record and continuity of occupation along the Cape south coast, and the Cape Floristic

76 Region (CFR) more generally, is a consequence of an unusually rich resource base unique to 77 this area (Parkington 2001, 2003, 2006; Marean, 2010, 2011). The coastline in this region offers 78 a highly productive inter-tidal zone for shellfish collection for human foragers. During glacial 79 phases, an extensive plain was exposed off the current coast that supported a diverse plains game 80 fauna, which would have offered excellent hunting opportunities (Klein, 1983; Marean, 2010).

81 The CFR is also home to a globally exceptional flora with many species offering harvestable 82 edible carbohydrates (Deacon, 1970, Parkington \& Poggenpoel, 1971; Van Wyk \& Gericke, 83 2000; Van Wyk, 2002; Schwegler, 2003; Dominy et al., 2008; De Vynck, Van Wyk \& Cowling, 84 2016). These include geophytic underground storage organs (USOs) that are both highly diverse 85 and locally abundant (Goldblatt, 1978; Procheş, Cowling \& du Preez, 2005; Procheş et al., 2006; 86 Singels et al., 2015), as well as many species with aboveground carbohydrates such as fruit, 87 vegetables, seed pods and seeds (De Vynck, Van Wyk \& Cowling, 2016). Together these 88 resources may have provided a complementary set of protein and carbohydrate-rich foods to a human forager, thus explaining the continuity of human occupation through glacial maxima. 
91 However, to date the actual availability and productivity of these potential food resources to a

92 human forager has been largely based on conjecture. For example, Marean's (2010) argument

93 that CFR geophyte diversity directly resulted in a wide range of collectable plant foods would

94 not hold if most of those plants were poisonous, very low in caloric returns, very costly to

95 procure, or unavailable for large parts of the year. To better understand the record for hunter-

96 gatherer foraging in this region, we must develop robust understandings of the foraging potential

97 of the plant foods. This includes analyses of their nutritional character (Kyriacou et al., 2014),

98 availability in the landscape and importantly their seasonal availability to a forager.

99

100 This study solely focuses on the temporal availability of edible carbohydrate from a range of

101 plant species in four vegetation types on South Africa's Cape south coast. Availability is

102 estimated based on the visibility of plant parts that directly or indirectly lead to edible

103

carbohydrate. We focus on visibility as a proxy for availability as human foragers primarily rely

104

on sight and have a poor sense of smell. Thus, above-ground edible carbohydrate may be readily

105

visible and available when plants are in fruit, but below-ground carbohydrate can only be found

106

if there are above-ground indicators such as leaves, flowers, or dried stalks. To the best of our

107 knowledge at this time, above ground visibility of plant foliage is the most reliable determinant

108

109

110

111

112

113

114

115

116

117

\section{Methods}

that a human forager could positively identify and extract the underground resource. The

ultimate goal is to combine these observations with studies of nutrition, abundance estimates and return rates, so as to contribute to the resourcescape for a paleoscape model for the Cape south coast (Marean et al., 2015). More generally, our paper adds to a growing literature on the importance of geophytes and aboveground carbohydrates to hunter-gatherer diet worldwide ( Kaye \& Moodie, 1978; Hatley \& Kappelman, 1980; Vincent, 1985; Murray et al., 2001; Bird, Bliege Bird \& Parker, 2005; Bliege Bird et al., 2008), and expands the range of variation of those data to a region that is megadiverse in plant species yet relatively unstudied in regards to plants, and geophytes in particular, as a food resource. 


\section{Study area}

121 The study area is situated in the coastal plain between the Breede and Gouritz rivers on the Cape 122 south coast (Fig. 1). The rainfall regime shows little seasonality and rain may fall at any time of 123 the year although slight rainfall peaks are observed in March-April and with more pronounced 124 peaks during August and October-November (Engelbrecht et al., 2014). The overall climate of 125 the study area is semi-arid to sub-humid with annual rainfall ranging from 350 to $550 \mathrm{~mm}$. The 126 three summer months (Dec-Feb) are the most stressful for plant growth, owing to generally 127 lower rainfall and persistently higher temperatures.

128

129 [Fig. 1 here]

130

Vegetation of the Cape coastal lowlands is under strong edaphic control (Thwaites \& Cowling, 132 1988; Rebelo et al., 1991; Cowling and Potts, 2015) and the study area has a wide range of 133 geologies which generate different soil types. These include Table Mountain Group sandstones 134 (visible on the coast), Bokkeveld shales (exposed on the inland margin of the study area), 135 Cretaceous Enon Formation conglomerates and mudstones ( $\sim 25 \mathrm{~km}$ from the coast), and 136 Bredasdorp Formation limestones (Rogers, 1984; Malan, 1987). In addition, near the coastal 137 margin aeolian sands of marine origin mantle the geology and this varies in $\mathrm{pH}$ with age; 138 younger sands are alkaline and older sands are leached and acidic (Rebelo et al., 1991; Abanda, 139 Compton \& Hannigan, 2011). Shale- and mudstone-derived soils are moderately fertile, while 140 those associated with leached sands are infertile. The calcareous sands associated with limestone, 141 calcrete and coastal dunes are also relatively infertile due to their high alkalinity and subsequent 142 low levels of plant-available phosphorus (Thwaites \& Cowling, 1988).

143

144 The Cape Floristic Region (CFR) is home to four biomes, namely Fynbos, Renosterveld, Forest 145 and Subtropical Thicket (Bergh et al. 2014). The vegetation types chosen for this study are 146 representative of dissected coastal margin of the southern CFR, namely Fynbos (two types), 147 Renosterveld and Subtropical Thicket (Rebelo et al., 1991). Generally, Fynbos communities are 148 richest in species, especially local endemics (Cowling, 1990); Renosterveld harbours a high 
149 diversity of USO-bearing geophytes (Proches et al., 2006 ), while Subtropical Thicket has a high 150 diversity of fruit-bearing trees and shrubs (Cowling et al., 1997).

151

152 This study monitored the phenological phase of edible plants - periodic life cycle events 153 growing in single plots located in Renosterveld, Sand Fynbos, Limestone Fynbos, and

154 Strandveld (a form of Subtropical Thcket). Renosterveld occurs on the relatively fertile and fine155 grained soils derived from shales and mudstones, and is a fire-prone grassy shrubland often 156 dominated by Elytropappus rhinocerotis (renosterbos). Sand Fynbos occurs on infertile acid soils 157 and is a fire-prone heath-like shrubland, characterised by the presence of Restionaceae and 158 Proteaceae. Limestone-derived soils support Limestone Fynbos, a highly endemic-rich 159 vegetation type (Willis et al., 1996). Marine sands are associated with Subtropical thicket, either 160 in its solid form or as thicket clumps in a matrix of Fynbos. This vegetation is colloquially 161 known as Strandveld. Plant compositional change, or beta diversity, between these edaphically 162 differentiated vegetation types is extremely high; consequently few species are shared among 163 these four vegetation types and regional-scale plant richness is very high (Cowling, 1990).

\section{Data collection}

166

167 The monitoring period was from May 2010 until April 2012. In the year prior to monitoring 168 (2009), the rainfall was far below average across all plots ( $70 \%$ of the mean annual rainfall).

169 The effects of the previously dry year were still evident when monitoring started. Above average 170 rainfall was experienced over the two years of monitoring (see Fig. S1 in supplementary 171 materials for climate diagrams and Fig. S2 for spatial relation of weather stations to survey 172 plots).

173

174 Monitoring plots were located in representative areas of each of the major vegetation types (one 175 plot per vegetation type) described above: Renosterveld, Sand Fynbos, Limestone Fynbos, and 176 Strandveld (Fig. 1). These plots were located within protected areas and were considered to be in 177 a pristine condition. Further biophysical data for the plots are provided in the supplementary 178 materials (Table S1). The Sand Fynbos site had burnt four years before the start of the survey 
179 period and this would likely have enhanced the visibility of USO species (Deacon, 1993), many

180 of which flower more profusely in the early post-fire years (Le Maitre \& Midgley, 1992).

181

182 Each plot was divided into six $20 \times 300 \mathrm{~m}$ transects (3.6 ha in total). Monitoring consisted of

183 surveying each plot every six weeks over a two-year period by one of the authors (JC De

184 Vynck), who is a trained field botanist familiar with the vegetation in this landscape. Along each

185 transect, the following were counted: 1) individuals of species bearing underground storage

186 organs (USOs) which would be apparent to a forager (i.e. in a phenological phase where one or

187 more aboveground organs were visible) and, 2) individuals of species with edible aboveground

188 carbohydrates; these included fruits, leaves, seed pods, seeds, and inflorescences. In our

189 sampling approach we adopted a forager's perspective by only including species known to be

190 edible (De Vynck, Van Wyk \& Cowling, 2016) and excluding any plants considered too small to

191 harvest. We included as edible any USOs that required cooking in order to render them edible

192 (e.g. tubers of Rhoicissus digitata and corms of Chasmanthe aethiopica and Watsonia spp.)

193 (Wells, 1965; Parkington \& Poggenpoel, 1971; Deacon, 1976, 1979; Liengme, 1987; Opperman

194 \& Heydenrych, 1990; Skead, Manning \& Anthony, 2009).

195

196 As stated above, availability of edible carbohydrates was based on direct or indirect visibility of

197 the resource. For example, USOs in their dormant phase are not visible aboveground and can

198 therefore not be procured by foragers. However, visible phases of USOs include any above

199 indicator of their presence, such as green leaves, flowers or dry wilted leaves. The nutritional

200 content may vary through these phases, but is not the focus of this study. The majority of species

201 with aboveground carbohydrates (e.g. fruiting species) are perennially visible, but were only

202 recorded as 'available' to foragers when edible carbohydrates were visible.

203

204 Data analysis

205

206 For each plot, the number of visible, and hence available, species with edible carbohydrates over

207 time was determined; this was calculated as the number of individuals observed in a given

208 survey that would provide access to edible carbohydrate divided by the maximum number of

209 individuals observed across all surveys (for a given species within a plot). In order to calculate 
210 the number of species with edible carbohydrate for a given period within a plot, the continuous

211 proportions of individuals with edible carbohydrate per species were converted to binary

212 presence or absence categories using a 10\% threshold. Thus, we considered edible carbohydrate

213 offered by a given species readily visible and available in the landscape if at least $10 \%$ of the

214 maximum observed individuals were visible with direct or indirect access to carbohydrates. The

215 number of species with edible carbohydrate considered available in each plot through time was

216 calculated. All analyses were conducted in R version 2.15 (R Development Core Team, 2014)

\section{Results}

219 Within the four 3.6 ha plots spread across the four vegetation types, 52 edible plant species were 220 recorded. Of these, 33 species were geophytes with edible underground storage organs (USOs) 221 and 21 species had aboveground edible carbohydrates (Table 1; see Table S3 and S4 in

222 supplementary materials for full species list per type). Note that some species had more than one 223 edible part. Richness of edible species varied across the vegetation types (Table 1): Limestone 224 Fynbos had the richest flora, followed by Strandveld, Renosterveld and lastly, Sand Fynbos. 225

226 [Table 1 here]

227

228 Species varied in the length of time they were available through the year [Fig. 2; see 229 supplementary materials for full list of species phenology diagrams (Table S2.1 to S2.8) and 230 phenphase synchronicity among the species (Fig. S3)]. Species with USOs were available for 231 longer periods of the year relative to those with edible aboveground carbohydrates. The 232 availability of USO species differed across vegetation types and between survey years (Fig. 3).

233 Nonetheless, the number of available USO species was highest for a six-month period from 234 winter to early summer (Jul-Dec) across all vegetation types. Months of lowest species' 235 availability were in mid-summer to early autumn (Jan-Apr); the early winter (May-Jun) values 236 were variable, being highest in Limestone Fynbos. In the wetter second year, the summer 237 "crunch" period - where few USO species were available - was at least one month shorter than 238 in the first year. The number of species with available edible aboveground carbohydrates also 
239 varied across vegetation types and sample years. Species richness peaked in spring (Sep-Nov) for

240 all vegetation types; relatively high availability extended into summer (Dec-Feb) but autumn and

241 early winter were lean months for harvesting aboveground carbohydrates in all vegetation types,

242 especially Renosterveld and Sand Fynbos. The presence of two Carpobrotus species, which bear

243 ripe fruits during the drier months, was a key factor for the extension of aboveground availability

244 period in Limestone Fynbos.

245 An impressive 25 species provided edible carbohydtate during the late summer (Feb - Mar)

246 "crunch period (Table 2). Twelve of these were USOs and Limestone Fynbos supported the

247 most species (16) with available carbohydrate present at this time.

248

249 [Fig. 2 here]

250 [Fig. 3 here]

251 [Table 2 here]

252

253 Discussion

254

255 Substantial archaeological evidence exists for the use of underground storage organs (USOs),

256 fruits and leaves by Late Stone Age peoples in southern Africa (Deacon \& Deacon, 1963;

257 Parkington \& Poggenpoel, 1971; Deacon, 1970, 1976, 1984; Opperman \& Heydenrych, 1990;

258 Deacon \& Deacon, 1999). This evidence is substantiated by direct observations of contemporary 259 hunter-gatherer communities in Africa (Lee, 1969, 1973, 1984; Silberbauer, 1981; Youngblood, 260 2004; Berbesque \& Marlowe, 2009; Marlowe \& Berbesque, 2009). The diversity and abundance 261 of edible plants, especially USOs, along the Cape coast, together with a rich source of both 262 marine and terrestrial based protein, has been hypothesised to be key components facilitating the 263 persistence of Middle Stone Age (MSA) people in the region during glacial phases when other 264 African regions may have been resource poor (Marean, 2010). However, very little research has 265 been conducted on the potential availability of food plants to hunter-gatherers on the Cape south 266 coast to corroborate this hypothesis. In the same study area, Singels et al. (2015) found 
267 surprisingly high edible biomass values for USOs (maximum values range from $600 \mathrm{~kg} / \mathrm{ha}$ in 268 Sand Fynbos to $5000 \mathrm{~kg} / \mathrm{ha}$ in Limestone Fynbos), although these were restricted to occasional

269 biomass hotspots within a matrix of much lower biomass. Also, these USO hotspots were found

270 within all vegetation types. Here we address the temporal availability of belowground (i.e.

271 USOs) and aboveground sources of carbohydrates across the four principal vegetation types of

272 the Cape south coast. We use this to speculate on the importance of carbohydrates as fallback

273 foods for coastal hunter-gatherers, and what role this may have played in the emergence of

274 cognitively modern people in the region (Marean, 2010).

275

276 The number of species with edible carbohydrate resources that are visible and available to

277 foragers was highest between winter and early summer in the study area. This is consistent with

278 the dominant cool-season phenology of plants in the Cape Floristic Region (Pierce, 1984). This

279 six-month period provides a diversity of USOs associated with corms belonging to petaloid

280 geophytes, mostly members of the Iridaceae (e.g. Babiana, Freesia, Gladiolus, Watsonia). These

281 species provide relatively large (10-100 g) starch-rich and low-fibre food parcels that are

282 inexpensive to harvest (Parkington, 1977; Deacon, 1993; Singels et al., 2015), and many do not

283 require cooking for digestion (Youngblood, 2004; Dominy et al., 2008; J. De Vynck pers. obs.,

284 2011). Also available during the cooler and mostly wetter months are fruits borne largely by

285 Subtropical thicket species (e.g. Carissa, Diospyros, Olea, Searsia) as well as leaf crops

286 (Trachyandra spp.). There are currently no data on the biomass, nutritional value and foraging

287 returns for aboveground sources of carbohydrate in the Cape Floristic Region. Fruit loads of

288 mature thicket shrubs and trees range from tens of thousands of fruits per plant for Sideroxylon

289 inerme (fruit diameter $10 \mathrm{~mm}$ ) and Searsia spp (3 mm) to fewer than 100 fruits for Euclea

290 racemosa $(7 \mathrm{~mm})$, Cassine tetragona $(8 \mathrm{~mm})$ and Osyris compressa $(20 \mathrm{~mm})$ (Cowling et al.,

291 1997). Mat-forming Carpobrotus species may bear several tens of large (35 mm diameter) fruits

292 (J. De Vynck pers. obs., 2011).

293

294 Late summer to early autumn periods have considerably fewer available edible species than in

295 the other times of the year. This is a period when all traces of leaves and inflorescences of the

296 dominant deciduous geophyte component have disappeared (Deacon, 1993). However, even

297 during this relatively warm and dry period, we recorded some 25 available species across the 
298 four vegetation types (Table 2). These include USOs such as hysteranthous, autumn-flowering 299 Gladiolus (cormous) and Pelargonium (tuberous) spp, the corms of evergreen Watsonia spp., 300 and the fibrous tubers of the evergreen liana, Rhoicissus digitata. Also apparent are the fruits 301 Carpobrotus spp, the fruits of many thicket shrubs and trees, and the leaf crop, Tetragonia 302 decumbens. Nonetheless, the late summer - early autumn months could represent a carbohydrate 303 "crunch" for foragers: at this time the number of edible plant species is at its lowest and the high304 biomass items available to foragers (e.g. Pelargonium spp., R. digitata) are fibrous and require 305 cooking for digestion (Deacon, 1995; Wandsnider, 1997; Laden \& Wrangham, 2005; Dominy et 306 al., 2008; Schnorr et al., 2015).

307

308 Overall, the plant-based carbohydrate resources available to Stone Age foragers of the Cape 309 south coast, especially USOs belonging to the Iridaceae (Deacon, 1976, 1993), are likely to have 310 comprised a reliable and nutritious source of calories over most of the year. Moreover, 311 availability of USOs showed little between-year variation, most likely due the existence of 312 sufficient storage reserves to enable at least leaf growth every year (Ruiters and McKenzie, 313 1994) despite variation in rainfall. In an assessment of foraging potential of six USO species 314 growing in our study area, Singels et al. (2015) showed that 50\% of foraging events conducted 315 yielded enough calories to meet the daily requirements of a hunter-gatherer of small stature 316 within two hours.

318 The juxtaposition within a 10 kilometre foraging radius of four major vegetation types, 319 belonging to three regional biomes (Fynbos, Renosterveld and Subtropical Thicket; Bergh et al., 320 2014), would have enabled humans to forage in very different resourcescapes on a daily basis.

321 While the Limestone Fynbos and Strandveld - the two vegetation types closest to the coast - are 322 likely to have offered the best foraging returns for much of the year, Renosterveld provides an 323 abundance of Iridaceae corms in the spring and Sand Fynbos harbours evergreen Watsonia spp., 324 which can be harvested during the late summer-autumn "crunch" (Singels et al., 2015).

325 Ethnographic evidence suggest that the harvesting of Iridaceae corms (uintjies) in spring was an 326 important event for the San of the Cape west coast (Van Vuuren, 2014). 
328 Given the temporal and spatial availability of edible plant species in the Cape, we argue that is

329 highly likely that USOs, fruit, seedpods, seeds, inflorescences and leaf crops were harvested as

330 fallback foods by Stone Age people living in this region. The likely preferred food for south

331 Cape coastal hunter-gatherers comprised the region's diverse and abundant marine resources

332 (Marean et al., 2007; Jerardino \& Marean, 2010; Parkington, 2010), and a diverse ungulate

333 plains fauna, including in the Pleistocene, several species of now extinct megafauna, associated

334 with the submerged Agulhas Bank (Klein, 1983; Parkington, 2001, 2003; Matthews, Marean \&

335 Nilssen, 2009; Marean, 2010; Faith, 2011). However, these resources were not always available

336 to harvesters and hunters, and the contraction and expansion of the Agulhas Plain ecosystem and

337 its ungulate communities must have been a major driver of changing foraging patterns on the

338 south coast (Marean et al., 2014). It has been hypothesized that the mammal fauna formed a

339 migratory community that moved west during the winter rains and east to intercept the summer

340 rains. Thus, the local abundance of many of the larger ungulates may have plummeted during

341 the winter months when populations migrated west to graze winter-growing grasses of the west

342 coast. Marine invertebrates, harvested from the intertidal, comprised the most reliable and

343 accessible source of protein for hunter-gatherers living on the Cape south coast (Marean, 2011).

344 Evidence for their use has been found in MSA sites such as Pinnacle Point (PP) 13B dating back

345 to $\sim 160 \mathrm{ka}$ (Marean et al., 2007; Jerardino \& Marean, 2010) and at early modern human sites that

346 date between 110-50 ka such as Blombos Cave (Henshilwood et al., 2001; Langejans et al.,

347 2012), and Klasies River Mouth (Voigt, 1973; Thackeray, 1988). Late Stone Age sites suggest an

348 increase in the intensity of intertidal foraging (Marean et al., 2014) and indications of resource

349 depletion (Klein \& Steele, 2013). Using experienced foragers of Khoe-San descent, J. De Vynck

350 et al. (unpublished data) showed exceptionally high peak return rates $\left(\sim 4,500 \mathrm{kcal} \mathrm{hr}^{-1}\right)$ from the

351 Cape south coast intertidal under ideal harvesting conditions. However, owing to tidal

352 constraints, and the fierce sea conditions experienced there, harvesting was only possible for 10

353 days a month, for 2-3 hours on each day; lowest returns were recorded in winter and spring - a

354 time of strong winds and high seas - and highest returns in summer and autumn, when sea

355 conditions were calmer (J. De Vynck et al., unpublished data). Consequently, there would have

356 been periods of various lengths - ranging from days to weeks - when hunter-gatherers depended

357 on, or fell back upon carbohydrates for sustenance. As pointed out above, the winter and early

358 spring months likely coincided with a scarcity of protein but an abundance of carbohydrates. At 
359 these times, plant carbohydrates, especially USOs, may have comprised $100 \%$ of dietary intake, 360 which would categorise them as a staple fallback food (Marshall \& Wrangham, 2007).

362 It has been hypothesized that the persistence of a small group of hominins on the Cape south 363 coast - as opposed to their widespread extinction elsewhere in Africa during Marine Isotope 364 Stage 6 (MIS6, 193000 -125 000 BP) (Foley, 1998; Lahr \& Foley, 1998; Fagundes et al., 2007; 365 Basell, 2008; Masson-Delmotte et al., 2010) - was a consequence of the Cape's relatively 366 moderate climate during the largely glacial MIS6 and its rich and diverse resource base. The 367 persistently warm Agulhas Current reduced the regional impact of glacial cooling substantially 368 (Negre et al., 2010; Zahn et al., 2010). Marean (2010) has hypothesised that during strong glacial 369 environments, such as those experienced in MIS6, the Cape south coast provided a unique 370 juxtaposition of resources important for hominin persistence, namely a diverse USO flora and a 371 rich and productive marine ecosystem. At that time the exposed Agulhas Plain (Fisher, Barr372 Matthews \& Marean, 2010) was mantled in substrata that likely supported Renosterveld, 373 Limestone Fynbos and Strandveld (Cawthra et al., 2015), offering a wide array of USOs, fruit 374 and leaf crops which would comprise reliable fallback foods when it was not possible to forage 375 in the intertidal and game was scarce. The cognitive challenges of exploiting marine resources 376 (e.g. comprehending lunar cycles), and defending them against competition from adjacent 377 groups, led to a coastal adaptation that may have contributed to the emergence of cognitively 378 modern Homo sapiens (Marean, 2011). Similarly, the ability to recognise which and when 379 vegetation types are most productive for carbohydrates, identifying hotspots of productivity and 380 distinguishing between edible and toxic USOs, must have been challenging (Deacon, 1995). 381 Here we have established the temporal availability of plant species with edible carbohydrates 382 across four dominant vegetation types along the south coast. Much additional research must be 383 done to evaluate more comprehensively the role of above- and belowground carbohydrates in the ecology and evolution of the human lineage in the Cape Floristic Region and elsewhere. Work is currently underway to establish the return rates of carbohydrate resources harvested by contemporary subjects of Khoe-San descent, in the different vegetation types and in different seasons; and on the rates of depletion of resources in successively harvested areas. This needs to

388 be complemented with data on the nutritional value of the consumed parts of the species selected. Ultimately, we aim to use these data to populate the carbohydrate resourcescape in an 
390 agent-based model aimed at predicting the effects of spatial and temporal variability - governed 391 by changes in climate and the resource base over the seasonal cycle as well as the glacial392 interglacial cycle of the Pleistocene - on the population size and structure, mobility, social 393 organization, territoriality, and technology of Cape hunter-gatherers (Marean et al., 2015). 394

\section{Acknowledgements}

396

397 We thank the Cape Nature team - Rhett Heismann, Jean Du Plessis and Leandi Wessels - for 398 access, support, information and GIS assistance. We also thank the Hessequa Municipality, and 399 in particular Hendrik Visser, for their help and support. The authors are also grateful for the 400 climate data supplied by South African Weather Service. Peter Henzi and an anonymous 401 reviewer provided valuable comments that improved the manuscript.

402

403 References

404

405 Abanda PA, Compton JS, Hannigan RE. 2011. Soil nutrient content, above-ground biomass and 406 litter in a semi-arid shrubland, South Africa. Geoderma 164 (3-4): 128-137.

407

408

Bar-Matthews M, Marean CW, Jacobs Z, Karkanas P, Fisher EC, Herries AIR, Brown K, 409 Williams HM, Bernatchez J, Ayalon, Nilssen PJ. 2010. A high resolution and continuous 410 isotopic speleothem record of paleoclimate and paleoenvironment from 90 to $53 \mathrm{ka}$ from 411 Pinnacle Point on the south coast of South Africa. Quaternary Science Reviews, 29 (17): 21314122145.

413

414 Basell LS. 2008. Middle Stone Age (MSA) site distributions in eastern Africa and their 415 relationship to Quaternary environmental change, refugia and the evolution of Homo sapiens. 416 Quaternary Science Reviews 27 (27): 2484-2498. 
418 Bergh NG, Verboom GA, Rouget M, Cowling RM. 2014. Vegetation types of the Greater Cape 419 Floristic Region. In: Allsopp N, Colville JF, Verboom T, eds. Fynbos: Ecology, Evolution, and 420 Conservation of a Megadiverse Region. , Oxford: Oxford University Press, 1-25.

421

422 Berbesque JC, Marlowe FW. 2009. Sex differences in food preferences of Hadza Hunter423 Gatherers. Evolutionary Psychology 7 (4): 601-616.

424

425 Bird DW, Bliege Bird RB, Parker CH. 2005. Aboriginal burning regimes and hunting strategies 426 in Australia's Western Desert. Human Ecology 33 (4): 443-464.

427

428 Bliege Bird RB, Bird DW, Codding BF, Parker CH, Jones JH. 2008. The "fire stick farming" 429 hypothesis: Australian Aboriginal foraging strategies, biodiversity, and anthropogenic fire 430 mosaics. Proceedings of the National Academy of Sciences 105: 14796-14801.

431

432 Cawthra HC, Compton JS, Fisher EC, MacHutchon MR, Marean CW. 2015. Submerged

433 shorelines and landscape features offshore of Mossel Bay, South Africa. Geological Society,

434 London, Special Publications 411: SP411-11.

435

436 Cowling RM. 1990. Diversity components in a species-rich area of the Cape Floristic Region. 437 Journal of Vegetation. Science 1: 699-710.

438

439 Cowling RM, Kirkwood D, Midgley JJ, Pierce SM. 1997. Invasion and persistence of bird440 dispersed, subtropical thicket and forest species in fire-prone fynbos. Journal of Vegetation 441 Science 8: 475-488.

442

443 Cowling RM, Potts AJ. 2015. Climatic, edaphic and fire regime determinants of biome

444 boundaries in the eastern Cape Floristic Region. South African Journal of Botany 101: 73-81. 445

446 Deacon HJ. 1970. Plant remains from Melkhoutboom Cave, South Africa. Proceedings Transkei 447 and Ciskei Research Society 1: 13-15. 
449 Deacon HJ. 1976. Where hunters gathered: a study of Holocene Stone Age people in the Eastern 450 Cape. Claremont: South African Archaeological Society.

451

452 Deacon HJ. 1979. Excavations at Boomplaas cave-a sequence through the upper Pleistocene and 453 Holocene in South Africa. World Archaeology 10 (3): 241-257.

454

455 Deacon HJ. 1993. Planting an Idea: An Archaeology of Stone Age Gatherers in South Africa.

456 The South African Archaeological Bulletin 48: 86-93.

457

458 Deacon HJ. 1995. Two late Pleistocene-Holocene archaeological depositories from the southern 459 Cape, South Africa. The South African Archaeological Bulletin 121-131.

460

461

Deacon J. 1984. Later Stone Age people and their descendants in southern Africa. In: Klein RG

462 ed. Southern African Prehistoric and Paleoenvironments. Rotterdam/Boston: A. A. Balkema, 463 220-328.

464

465

Deacon HJ, Deacon J. 1963. Scott's Cave: a late Stone Age site in the Gamtoos Valley Annals of 466 the Cape Provincial Museums. Natural History 3: 96-112.

467

468

Deacon HJ, Deacon J. 1999. Human beginnings in South Africa: Uncovering the secrets of the

469 Stone Age. Cape Town: David Philip Publishers (Pty) Ltd.

470

471 De Vynck JC, Van Wyk BE, Cowling RM. 2016. Indigenous Edible Plant Use by Contemporary 472 Khoe-San Descendants of South Africa's Cape South Coast. South African Journal of Botany 473 102: 60-69.

474

475 Dominy NJ, Vogel ER, Yeakel JD, Constantino P, Lucas PW. 2008. Mechanical properties of 476 plant underground storage organs and implications for dietary models of early Hominins.

477 Evolutionary Biology 35: 159-175. 
479 Engelbrecht CJ, Landman WA, Engelbrecht FA, Malherbe J. 2014. A synoptic decomposition of 480 rainfall over the Cape south coast of South Africa. Climate Dynamics 44 (9-10): 2589-2607. 481

482 Fagundes NJ, Ray N, Beaumont M, Neuenschwander S, Salzano FM, Bonatto SL, Excoffier L. 483 2007. Statistical evaluation of alternative models of human evolution. Proceedings of the 484 National Academy of Sciences 104 (45): 17614-17619.

485

486 Faith JT. 2011. Ungulate community richness, grazer extinctions, and human 487 subsistence behavior in southern Africa's Cape Floral Region. Palaeogeography, 488 Palaeoclimatology, Palaeoecology 306 (3): 219-227.

489

490 Fisher EC, Bar-Matthews MJA, Marean CW. 2010. Middle and Late Pleistocene paleoscape 491 modeling along the southern coast of South Africa. Quaternary Science Reviews 29 (11): 13824921398.

493

494 Foley R. 1998. The context of human genetic evolution. Genome Research 8 (4): 339-347. 495

496 Goldblatt P. 1978. An analysis of the flora of Southern Africa: its characteristics, relationships, 497 and origins. Annals of the Missouri Botanical Gardens 65: 369-436.

498

499 Hatley T, Kappelman J. 1980. Bears, pigs, and plio-Pleistocene Hominids: A case for the 500 exploitation of belowground food resources. Human Evolution 8: 371-387.

501

502 Henshilwood CS, Sealy JC, Yates R, Cruz-Uribe K, Goldberg P, Grine FE, Klein RG, 503 Poggenpoel C, van Niekerk K, Watts I. 2001. Blombos Cave, southern Cape, South Africa: 504 preliminary report on the 1992-1999 excavations of the Middle Stone Age levels. Journal of 505 Archaeological Science 28 (4): 421-448.

506

507 Jerardino A, Marean CW. 2010. Shellfish gathering, marine paleoecology and modern human 508 behavior: perspectives from cave PP13B, Pinnacle Point, South Africa. Journal of Human 509 Evolution 59 (3-4): 412-424. 
511 Kaye B, Moodie DW. 1978. The Psoralea food resource of the Northern Plains. Plains

512 Anthropologist 23: 329-36

513

514 Klein RG. 1983. Palaeoenvironmental implications of Quaternary large mammals in the fynbos 515 region. In: Deacon HJ, Hendey QB, Lambrechts JJN, eds. Fynbos Paleoecology: a preliminary 516 synthesis. Pretoria: South African National Scientific Programmes Report, 75: 116-138.

517

518 Klein RG, Steele TE. 2013. Archaeological shellfish size and later human evolution in Africa.

519 Proceedings of the National Academy of Science 110 (27): 10910-10915.

520

521 Kyriacou K, Parkington JE, Marais AD, Braun DR. 2014. Nutrition, modernity and the 522 archaeological record: Coastal resources and nutrition among Middle Stone Age hunter-gatherers 523 on the western Cape coast of South Africa. Journal of Human Evolution 77: 64-73.

524

525 Laden G, Wrangham R. 2005. The rise of the hominids as an adaptive shift in fallback foods:

526 plant underground storage organs (USOs) and australopith origins. Journal of Human Evolution 52749 (4): 482-498.

528

529 Lahr MM, Foley RA. 1998. Towards a theory of modern human origins: geography, 530 demography, and diversity in recent human evolution. Yearbook of Physical Anthropology, 41:

531 137-176.

532

533 Langejans GHJ, van Niekerk KL, Dusseldorp GL, Thackeray JF. 2012. Middle Stone Age 534 shellfish exploitation: Potential indications for mass collecting and resource intensification at 535 Blombos Cave and Klasies River, South Africa. Quaternary International 270: 80-94.

536

537 Lee RB. 1969. !Kung Bushman subsistence: An input-output analysis. In: Vayda AP, ed.

538 Environment and Cultural Behaviour. Austin: University of Texas Press, 47-79. 
540 Lee RB. 1973. Mongongo: The ethnography of a major wild food resource. Ecology of Food and

541 Nutrition 2 (4): 213-307.

542

543 Lee RB. 1984. The Dobe!Kung. New York: Holt, Rinehart and Winston, Inc., 40-44.

544

545 Le Maitre DC, Midgley JJ. 1992. Plant reproductive ecology. In: Cowling RM, ed. The ecology

546 of Fynbos: nutrients, fire and diversity. Cape Town: Oxford University Press, 135-174.

547

548 Liengme C. 1987. Botanical remains from archaeological sites in the Western Cape. Paper in the 549 prehistory of the Western Cape. Oxford: BAR International Series, 237-261.

550

551 Malan JA. 1987. The Bredasdorp Group in the area between Gans Bay and Mossel Bay. South 552 African Journal of Science 83 (8): 506-507.

553

554 Marean CW. 2010. Pinnacle Point Cave 13B (Western Cape Province, South Africa) in context:

555 the Cape Floral kingdom, shellfish, and modern human origins. Journal of Human Evolution 59

556 (3-4): 425-443.

557

558 Marean CW. 2011. Coastal South Africa and the coevolution of the modern human lineage and 559 the coastal adaptation. In: Bicho NS, Haws JA, Davis LG, eds. Trekking the shore.

560 Interdisciplinary contributions to Archaeology. New York: Springer, 421-440.

561

562 Marean CW, Bar-Matthews M, Bernatchez J, Fisher E, Goldberg P, Herries AIR, Jacobs Z, 563 Jerardino A, Karkanas P, Minichillo T, Nilssen PJ, Thompson E, Watts I, Williams HM. 2007.

564 Early human use of marine resources and pigment in South Africa during the Middle

565 Pleistocene. Nature 449 (7164): 905-908.

566

567 Marean CW, Cawthra HC, Cowling, RM, Esler KJ, Fisher E, Milewski A, Potts AJ, De Vynck 568 JC. 2014. Stone Age People in a Changing South African Greater Cape Floristic Region. In: 569 Allsopp N, Colville JF, Verboom T, eds. Fynbos: Ecology, Evolution, and Conservation of a 570 Megadiverse Region. Oxford: Oxford University Press, 164-199. 
571

572 Marean CW, Anderson RJ, Bar-Matthews M, Braun K, Cawthra HC, Cowling RM, Engelbrecht

573 F, Esler KJ, Fisher E, Franklin J, Hill K, Janssen M, Potts AJ, Zahn R. 2015. A new research

574 strategy for integrating studies of paleoclimate, paleoenvironment, and paleoanthropology.

575 Evolutionary Anthropology: Issues, News, and Reviews 24 (2): 62-72.

576

577 Marshall A, Wrangham R. 2007. Evolutionary consequences of fallback foods. International

578 Journal of Primatology 28: 1219-1235.

579

580 Marlowe FW, Berbesque JC. 2009. Tubers as fallback foods and their impact on Hadza Hunter-

581 Gatherers. American Journal of Physical Anthropology 140 (4): 751-758.

582

583 Masson-Delmotte V, Stenni B, Pol K, Braconnot P, Cattani O, Falourd S, Kageyama M, Jouzel

584 J, Landais A, MinsterB, Barnola JM, Chappellaz J, Krinner G, Johnsen S, Rothlisberger R, 585 Hansen J, Mikolajewicz U, Otto-Bliesner B. 2010. EPICA Dome C record of glacial and 586 interglacial intensities. Quaternary Science Reviews 29(1): 113-128.

587

588 Matthews T, Marean CW, Nilssen, PJ. 2009. Micromammals from the Middle Stone Age (92

$589000-167000 \mathrm{ka}$ ) at Cave PP13B, Pinnacle Point, south coast, South Africa. Paleontologia 590 Africana 4: 112-120.

591

592 Murray SS, Schoeninger MJ, Bunn HT, Pickering TR, Marlett, J. A. 2001. Nutritional

593 Composition of Some Wild Plant Foods and Honey Used by Hadza Foragers of Tanzania.

594 Journal of Food Composition and Analysis 14: 3-13.

595

596 Negre C, Zahn R, Thomas AL, Masqué P, Henderson GM, Martínez-Méndez G, Hall IR, Mas 597 JL. 2010. Reversed flow of Atlantic deep water during the Last Glacial Maximum. Nature 468 598 (7320): 84-88.

599 
600 Opperman H, Heydenrych B. 1990. A 22000 Year-Old Middle Stone Age camp site with plant 601 food remains from the North-Eastern Cape. The South African Archaeological Bulletin 45 (152): 602 93-99.

603

604 Parkington JE. 1977. Soaqua: Hunter-fisher-gatherers of the Olifants River valley Western Cape. 605 South African Archaeological Society 32: 150-157.

606

607 Parkington JE. 2001. Milestones: the impact of the systematic exploitation of marine foods on 608 human evolution. In: Tobias PV, Raath MA, Moggi-Cecci J, Doyle GA, eds. Humanity from 609 African naissance to coming Millennia - colloquia in human biology and palaeoanthropology. 610 Firenze: Firenze University Press, 327-336.

611

612 Parkington J. 2003. Middens and moderns: shellfishing and the Middle Stone Age of the Western 613 Cape, South Africa. South African Journal of Science 99 (5/6): 243.

614

615 Parkington J. 2006. Shorelines, strandlopers and shell middens: Archaeology of the Cape Coast. 616 Cape Town: Krakadouw.

617

618 Parkington J. 2010. Coastal diet, encephalization, and innovative behaviors in the late Middle 619 Stone Age of southern Africa. Human Brain Evolution: The Influence of Freshwater and Marine 620 Food Resources. New York: Wiley-Blackwell, 189-202.

621

622 Parkington JE, Poggenpoel C. 1971. Excavations at de Hangen, 1968. The South African 623 Archaeological Bulletin 26: 3-26.

624

625 Pierce SM. 1984. A synthesis of plant phenology in the Fynbos Biome. South African National 626 Scientific Programmes Report no. 88. Pretoria: Graphics art division of the CSIR, 29. 627

628 Procheş S, Cowling RM, du Preez DR. 2005. Patterns of geophyte diversity and storage organ 629 size in the winter-rainfall region of southern Africa. Diversity and Distributions 11 (1): 101-109. 630 
631 Procheş S, Cowling RM, Goldblatt P, Manning JC, Snijman DA. 2006. An overview of the Cape 632 geophytes. Biological Journal of the Linnean Society 87 (1): 27-43.

633

634 R Development Core Team. 2014. R: A language and environment for statistical computing.

635 Vienna, Austria: R Foundation for Statistical computing, ISBN 3-900051-07-0, URL

636 http://www.R-project.org

637

638 Rebelo AG, Cowling RM, Campbell BM, Meadows M. 1991. Plant communities of the

639 Riversdale plain. South African Journal of Botany 57: 10-28.

640

641 Rogers J. 1984. Cenozoic geology of the southern Cape coastal plain between Cape Agulhas and 642 Mossel Bay, focussing on the area between the Kafferkuils and Gouritz rivers. Technical report 643 No. 15: University of Cape Town: Marine Geoscience Unit.

644

645 Ruiters C, McKenzie B. 1994. Seasonal allocation and efficiency patterns of biomass and 646 resources in the perennial geophyte Sparaxis grandiflora subspecies fimbriata (Iridaceae) in 647 lowland coastal fynbos, South Africa. Annals of Botany 74 (6): 633-646.

648

649 Schnorr SL, Crittenden AN, Venema K, Marlowe FW, Henry AG. 2015. Assessing digestibility 650 of Hadza tubers using a dynamic in-vitro model. American Journal of Physical Anthropology $651158(3): 371-385$.

652

653 Schwegler M. 2003. Medicinal and Other Uses of Southern Overberg Fynbos Plants. Cape

654 Town: M. Schwegler.

655

656 Silberbauer GB. 1981. Hunter and habitat in the central Kalahari Desert. Cambridge:

657 Cambridge University Press.

658

659 Singels E, Potts AJ, Esler KJ, Cowling RM, Marean CW, De Vynck JC. 2015. Foraging potential 660 of underground storage organ plants in the southern Cape, South Africa. PeerJ PrePrints 3:e1962 661 https://doi.org/10.7287/peerj.preprints.1573v1 
662

663 Skead CJ, Manning JC, Anthony NC. 2009. Historical plant incidence in southern Africa: a

664 collection of early travel records in southern Africa. Pretoria: South African National

665 Biodiversity Institute.

666

667 Thackeray JF. 1988. Molluscan Fauna from Klasies River, South Africa. South African

668 Archaeological Bulletin 43: 27-32.

669

670 Thwaites RN, Cowling RM. 1988. Soil-vegetation relationships on the Agulhas plain, South 671 Africa. Catena 15 (3): 33345.

672

673 Van Vuuren H. 2014. 'A song sung by the star !Gaunu, and especially by Bushman women': the

674 blossoming of the uintjieblom. In: Deacon J, Skotnes P. The courage of //kaboo. Celebrating the 675 100th anniversary of the publication of Specimens of Bushman Folklore. Cape Town: UCT

676 Press, 317-328.

677

678 Van Wyk BE. 2002. A review of ethnobotanical research in South Africa. South African Journal 679 of Botany 68: 1-13.

680

681 Van Wyk BE, Gericke N. 2000. People's plants: a guide to useful plants of southern Africa.

682 Johannesburg: Briza Publications.

683

684 Vincent AS. 1985. Underground Plant Foods and Subsistence in Human Evolution. California:

685 University of California at Berkeley.

686

687 Voigt E, 1973. Klasies River Mouth Cave: An exercise in shell analysis. Bulletin of the

688 Transvaal Museum 14: 14-15.

689

690 Wandsnider L. 1997. The roasted and the boiled: food composition and heat treatment with 691 special emphasis on pit-hearth cooking. Journal of Anthropological Archaeology, 16 (1): 1-48. 692 
693 Wells MJ. 1965. An analysis of plant remains from Scott's Cave in the Gamtoos Valley. The 694 South African Archaeological Bulletin 79-84.

695

696 Willis CK, Lombard AT, Cowling RM, Heydenrych BJ, Burgers CJ. 1996. Reserve systems for 697 limestone endemic flora of the Cape lowland fynbos: iterative versus linear programming.

698 Biological Conservation 77 (1): 53-62.

699

700 Youngblood D. 2004. Identification and quantification of edible plant foods in the Upper (Nama)

701 Karoo, South Africa. Economic Botany 58 (1): 43-65.

702

703 Zahn R, Lutjeharms J, Biastoch A, Hall I, Knorr G, Park W, Reason C. 2010. Investigating the

704 global impacts of the Agulhas Current. Eos, Transactions American Geophysical Union 91 (12):

705 109-110.

706

707 
708 Table 1: Summary of edible species in 3.6 ha plots situated in four dominant vegetation types 709 along the Cape south coast.

\begin{tabular}{lcccc} 
& USOs & Fruit & Other ${ }^{1}$ & All \\
\hline Renosterveld & 8 & 6 & 2 & 16 \\
Sand Fynbos & 5 & 4 & 1 & 10 \\
Limestone Fynbos & 21 & 11 & 7 & 39 \\
Strandveld & 15 & 8 & 5 & 28 \\
\hline Across all types $^{2}$ & 33 & 14 & 8 & 52
\end{tabular}

7101 'Other' includes species with edible: seed pods, seeds, leaves, and inflorescences.

$711{ }^{2}$ Note that this is the number of unique species (i.e. some species are shared between vegetation types or 712 have more than one edible part).

713

714

715 
716 Table 2: Species available during the 'carbohydrate-crunch' late summer period (February-

717 March) in both survey years.

718

\begin{tabular}{|c|c|c|}
\hline Vegetation type & Carbohydrate category & Species \\
\hline \multirow[t]{2}{*}{ Renosterveld } & Underground storage organ & $\begin{array}{l}\text { Babiana patula; Cyphia digitata; Watsonia } \\
\text { meriana }\end{array}$ \\
\hline & Aboveground & $\begin{array}{l}\text { Diospyros dichrophylla (fruit); Osyris compressa } \\
\text { (fruit); Sideroxylon inerme (fruit) }\end{array}$ \\
\hline \multirow[t]{2}{*}{$\begin{array}{l}\text { Limestone } \\
\text { Fynbos }\end{array}$} & Underground storage organ & $\begin{array}{l}\text { Cyphia digitata; Gladiolus exilis; Pelargonium } \\
\text { lobatum; Pelargonium triste; Rhoicissus digitata; } \\
\text { Watsonia fergusoniae }\end{array}$ \\
\hline & Aboveground & $\begin{array}{l}\text { Carissa bispinosa (fruit); Carpobrotus } \\
\text { accinaciformis (fruit); Carpobrotus edulis (fruit); } \\
\text { Cynanchum obtusifolium (seedpods); Euclea } \\
\text { racemosa (fruit); Osyris compressa (fruit); Searsia } \\
\text { glauca (fruit); Sideroxylon inerme (fruit); } \\
\text { Tetragonia decumbens (leaves); Zygophyllum } \\
\text { morgsana (seed) }\end{array}$ \\
\hline \multirow[t]{2}{*}{ Sand Fynbos } & Underground storage organ & Gladiolus guthriei; Watsonia fourcadei \\
\hline & Aboveground & Carpobrotus edulis \\
\hline \multirow[t]{2}{*}{ Strandveld } & Underground storage organ & $\begin{array}{l}\text { Chasmanhte aethiopica; Ferraria crispa; } \\
\text { Rhoicissus digitata }\end{array}$ \\
\hline & Aboveground & $\begin{array}{l}\text { Carissa bispinosa (fruit); Carpobrotus } \\
\text { accinaciformis (fruit); Osteospermum moniliferum } \\
\text { (fruit); Schotia afra (seed); Tetragonia decumbens } \\
\text { (leaves) }\end{array}$ \\
\hline
\end{tabular}




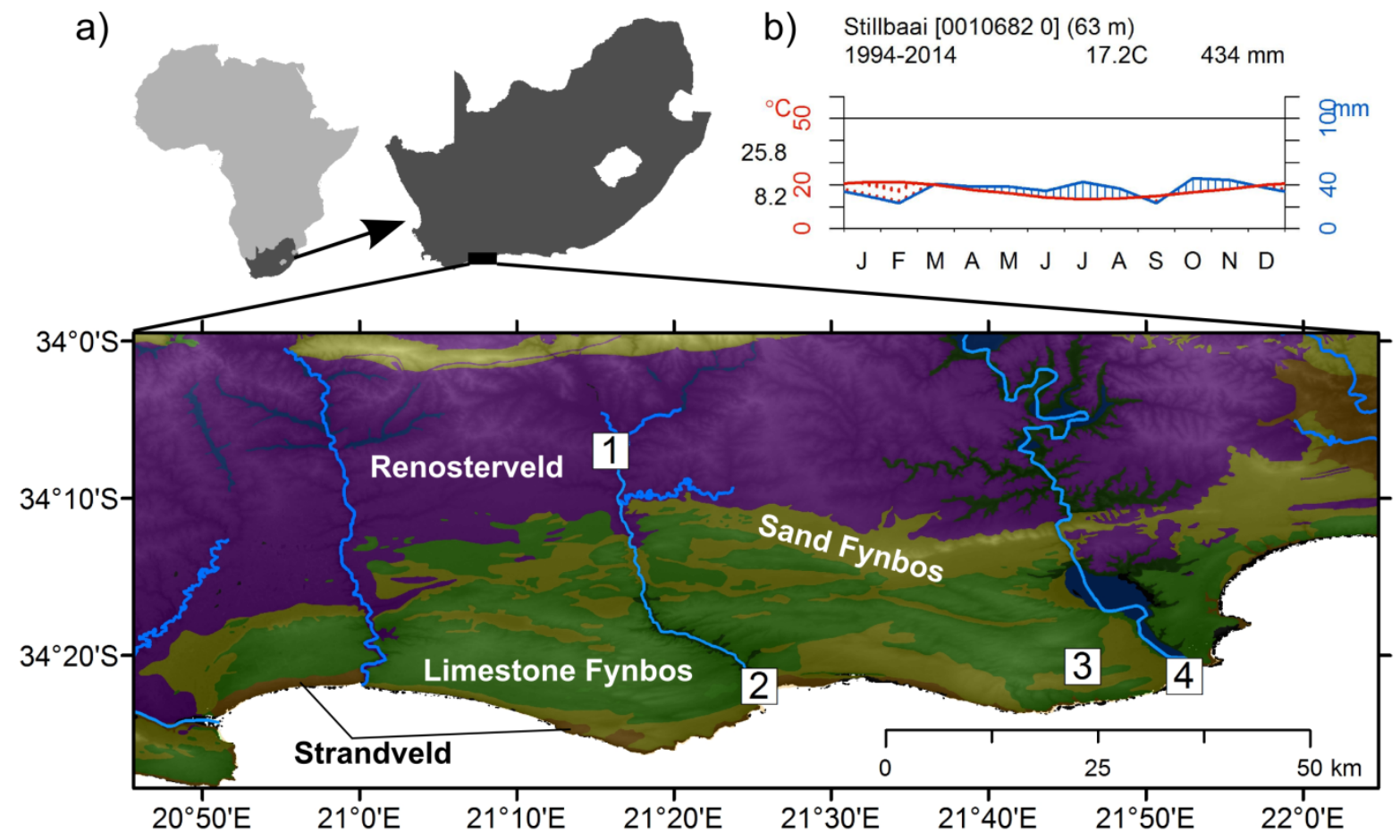

c)
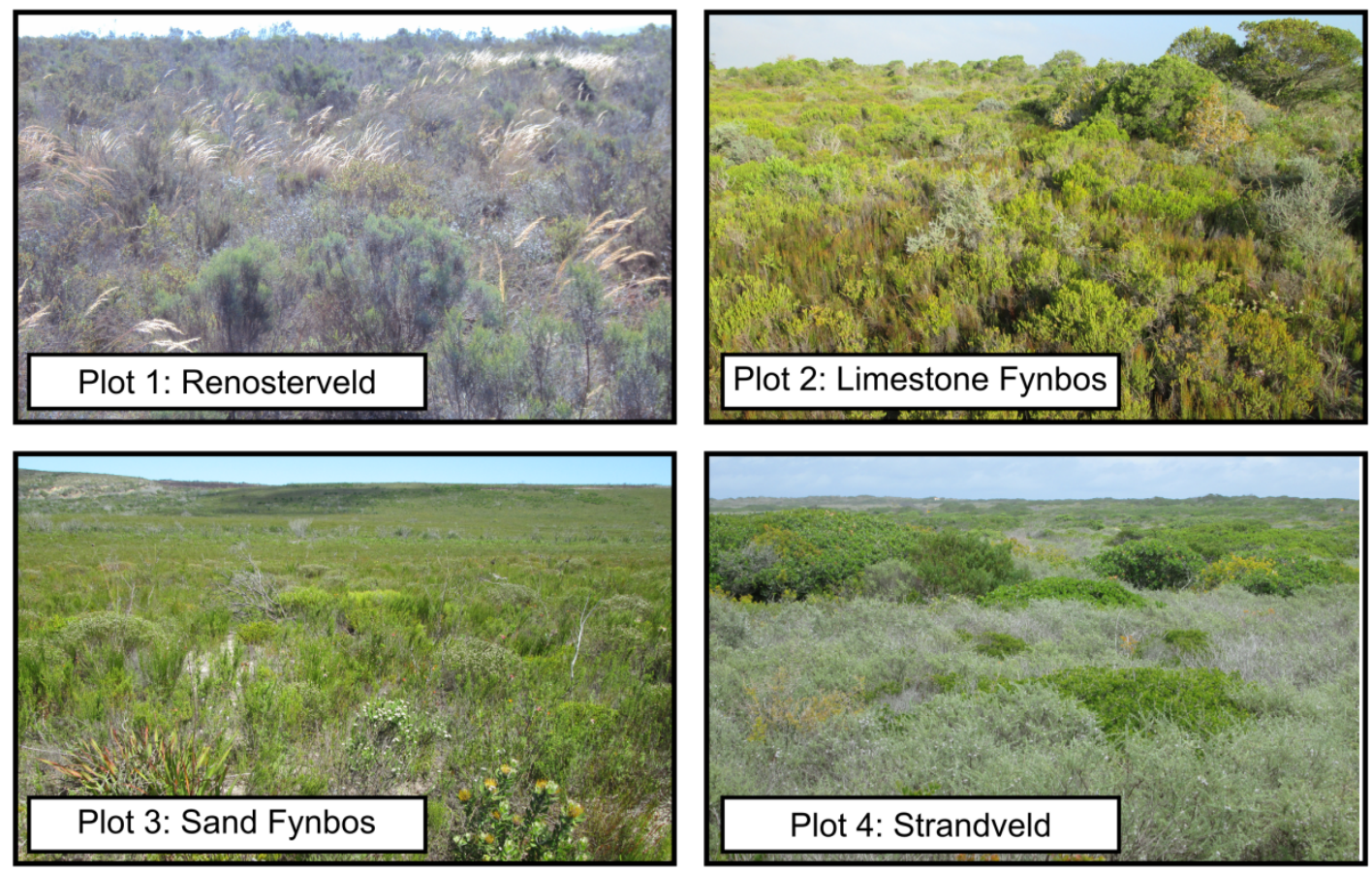

720 Figure 1: a) The location and major vegetation types of the study region and the plot localities [1:

721 Renosterveld (purple); 2: Limestone Fynbos (green); 3: Sand Fynbos (yellow); and 4: Strandveld

722 (orange; restricted to the coastal margin; see Tabe S1 for further plot details)]. b) A Walter-Leith 
723 climate diagram from the town of Still Bay ( $\sim 5 \mathrm{~km}$ from plot 2$)$. c) Photos taken within the four 724 plots in the different vegetation types.

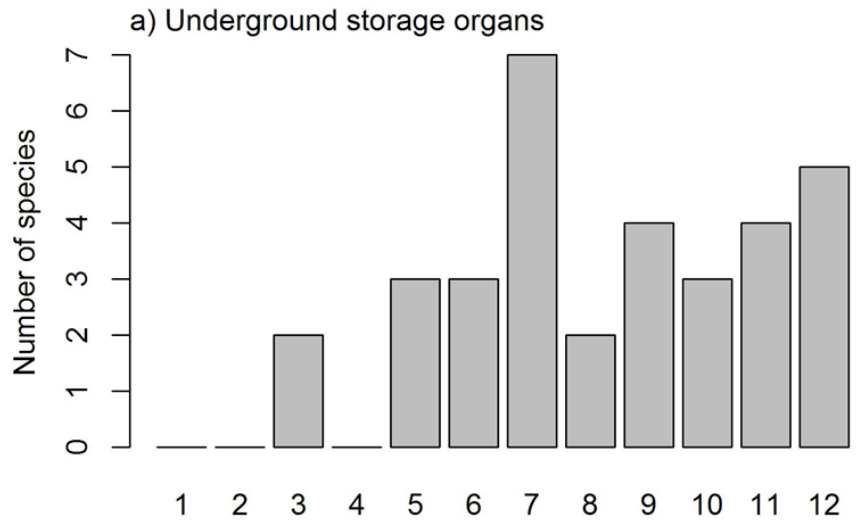

b) Aboveground carbohydrate

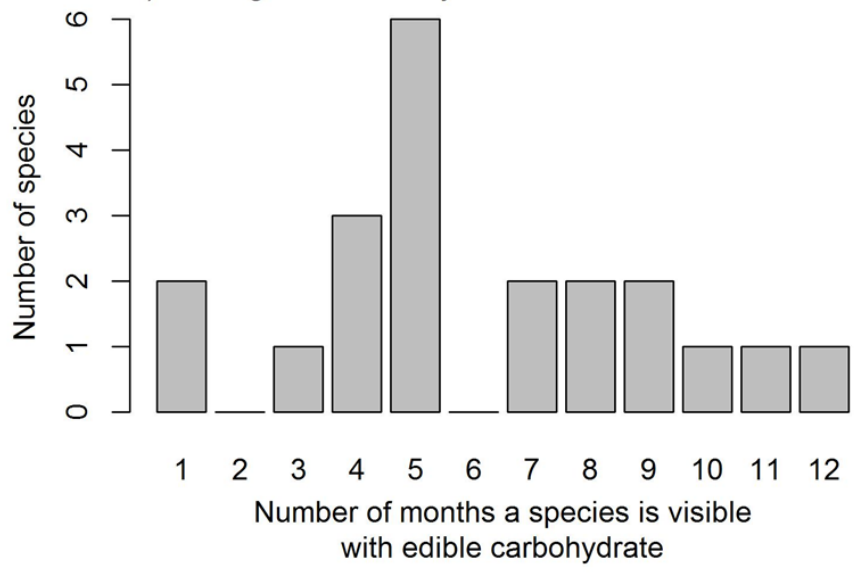
with edible carbohydrate

728 Figure 2: A breakdown of the number of months in which different plant species (with edible carbohydrates) are visible through the year separated into a) underground storage organs (USOs) and b) aboveground carbohydrate (e.g fruit, seed pods, seeds, leaves or inflorescences). 
a) Limestone Fynbos

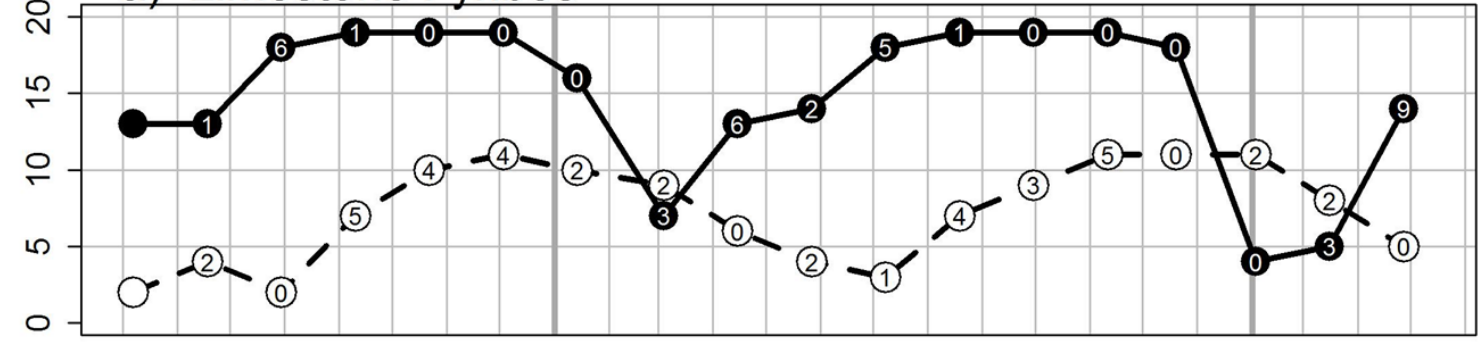

b) Sand Fynbos

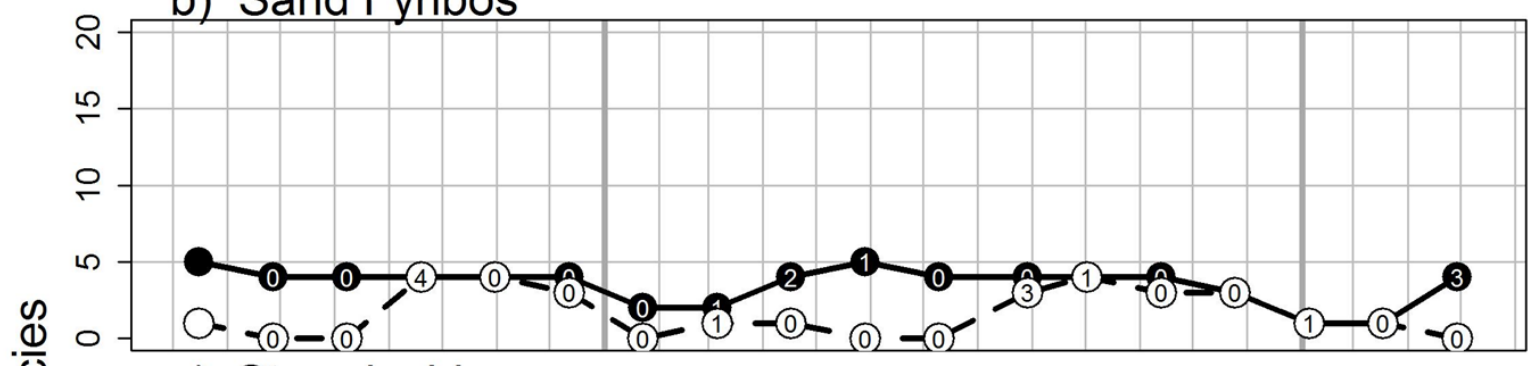

$\frac{1}{0}$
$\frac{1}{0}$
$\frac{0}{3}$
$\frac{1}{0}$
$\frac{1}{0}$
$\frac{0}{2}$
$\frac{1}{2}$

c) Strandveld

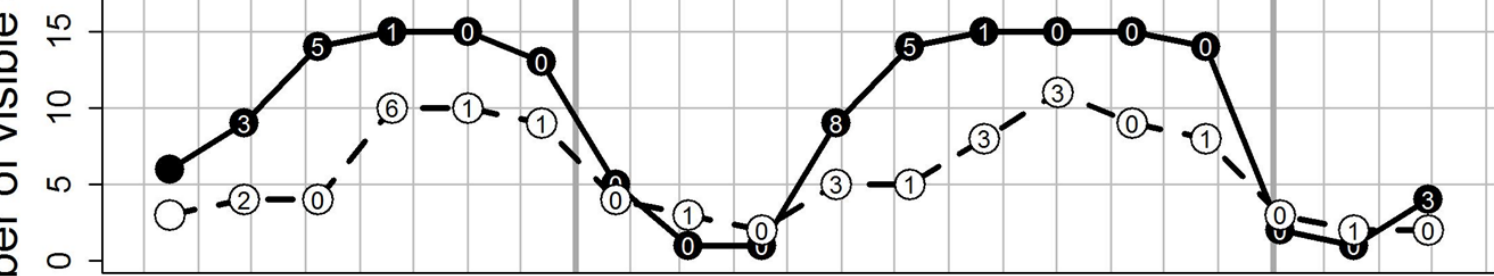

$\frac{\mathrm{s}}{3}$ d) Renosterveld

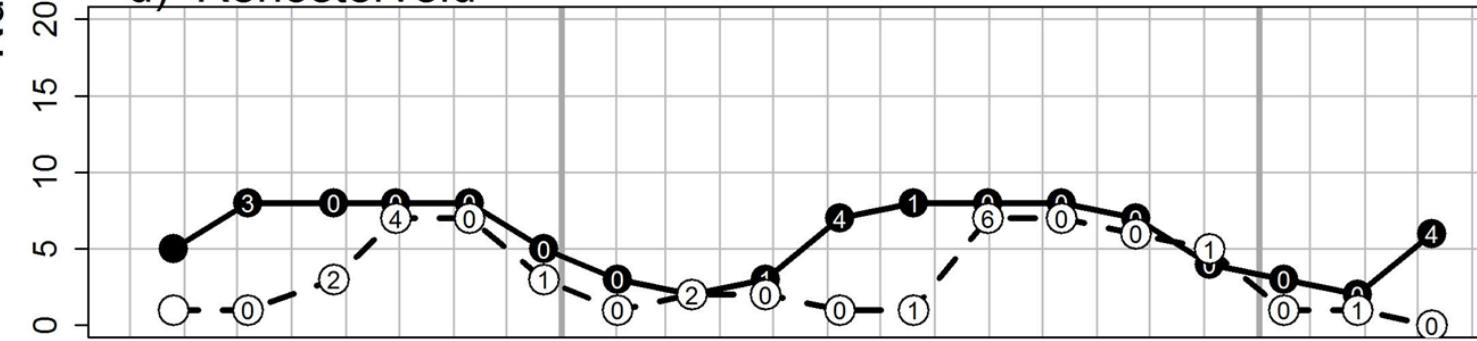

e) Across all vegetation types

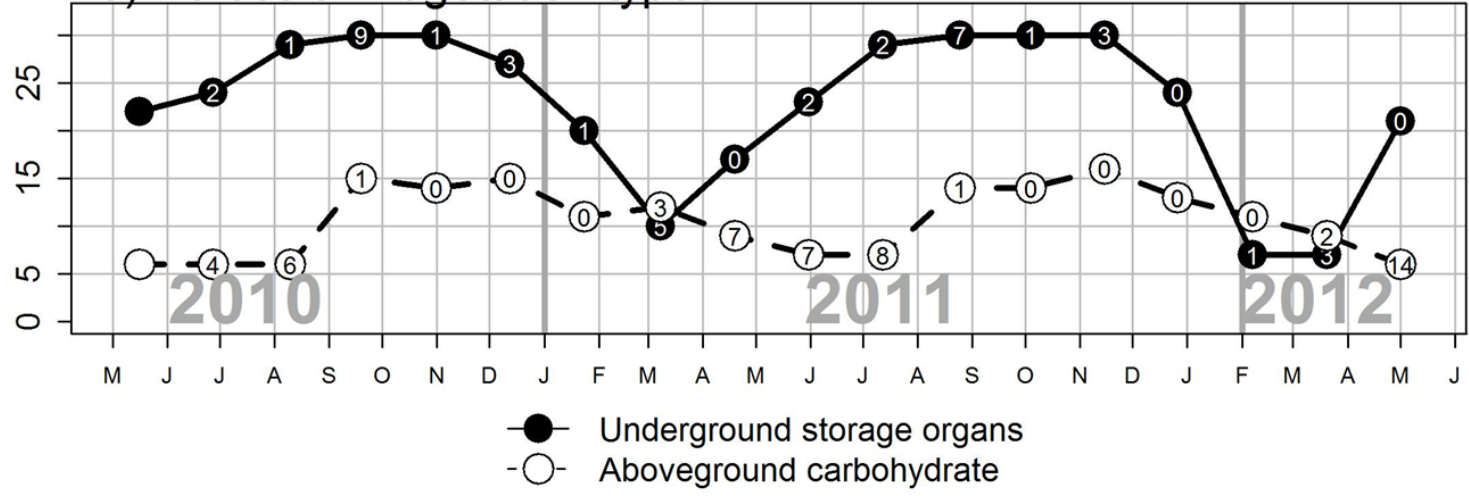


732 Figure 3: The seasonal availability of edible species visible to a human forager in four vegetation 733 types dominant along the Cape south coast. Underground storage organs are geophytes that have 734 tubers, corms, bulbs or rhizomes, while above-ground carbohydrate includes specie with edible 735 fruit, seed pods, seeds, leaves or inflorescences. The number of new species observed since the 736 previous survey is shown in each circle; this provides an indication of species turnover. 